OPEN ACCESS

Edited by:

Mark S. Cragg,

University of Southampton,

United Kingdom

Reviewed by:

Salah Mécheri

Institut Pasteur, France

Ulrich Blank,

Institut National de la Santé et de la

Recherche Médicale (INSERM).

France

*Correspondence:

Gregorio Gomez

gregorio.gomez@uscmed.sc.edu

Specialty section:

This article was submitted to

Molecular Innate Immunity,

a section of the journal

Frontiers in Immunology

Received: 29 November 2018

Accepted: 21 January 2019

Published: 07 February 2019

Citation:

Gomez G (2019) Current Strategies to Inhibit High Affinity FCERI-Mediated Signaling for the Treatment of Allergic Disease. Front. Immunol. 10:175. doi: 10.3389/fimmu.2019.00175

\title{
Current Strategies to Inhibit High Affinity FceRI-Mediated Signaling for the Treatment of Allergic Disease
}

\section{Gregorio Gomez*}

Department of Pathology, Microbiology and Immunology, University of South Carolina School of Medicine, Columbia, SC, United States

Allergies and asthma are a major cause of chronic disease whose prevalence has been on the rise. Allergic disease including seasonal rhinitis, atopic dermatitis, urticaria, anaphylaxis, and asthma, are associated with activation of tissue-resident mast cells and circulating basophils. Although these cells can be activated in different ways, allergic reactions are normally associated with the crosslinking of the high affinity Fc receptor for Immunoglobulin E, Fc\&RI, with multivalent antigen. Inflammatory mediators released from cytoplasmic granules, or biosynthesized de novo, following FceRl crosslinking induce immediate hypersensitivity reactions, including life-threatening anaphylaxis, and contribute to prolonged inflammation leading to chronic diseases like asthma. Thus, inappropriate or unregulated activation of mast cells and basophils through antigenic crosslinking of Fc\&Rl can have deleterious, sometimes deadly, consequences. Accordingly, Fc\&RI has emerged as a viable target for the development of biologics that act to inhibit or attenuate the activation of mast cells and basophils. At the forefront of these strategies are (1) Anti-IgE monoclonal antibody, namely omalizumab, which has the secondary effect of reducing Fc\&Rl surface expression, (2) Designed Ankyrin Repeat Proteins (DARPins), which take advantage of the most common structural motifs in nature involved in protein-protein interactions, to inhibit FC\&RI-IgE interactions, and (3)

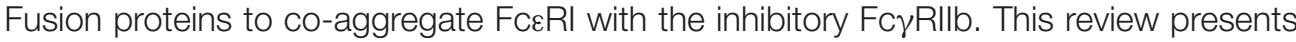
the published research studies that support omalizumab, DARPins, and fusion proteins as, arguably, the three most currently viable strategies for inhibiting the expression and activation of the high affinity FcERI on mast cells and basophils.

\section{Keywords: Fc£RI, allergy, omalizumab, DARPin, fusion protein, mast cells, basophils, Fc $\gamma$ RIlb}

\section{INTRODUCTION}

Allergic disease refers to a variety of disorders that include seasonal allergies, atopic dermatitis, urticaria, life-threatening anaphylaxis reactions to food, and allergic asthma. Curiously, the incidence of allergic disease has increased dramatically in recent decades, and continues to rise in developed countries. Allergies and asthma are among the most prevalent chronic diseases worldwide $(1,2)$. The culprits are a variety of pre-formed inflammatory mediators including histamine, serine proteases, proteoglycans, and other enzymes, that are stored in cytoplasmic granules and released from mast cells and basophils immediately following "degranulation," and eicosanoids like prostaglandins and leukotrienes that are very rapidly biosynthesized from 
arachidonic acid. Prolonged stimulation also induces the activation of various transcription factors, and synthesis of new cytokines that contribute to inflammation and recruitment of other cell types.

Mast cells can be activated by a variety of agents. However, allergic reactions are generally associated with crosslinking of the high affinity Fc receptor for immunoglobulin E (IgE), FceRI, with multivalent antigen (3). High affinity FcERI is comprised of an IgE-binding $\alpha$ chain, a signal enhancing $\beta$ chain, and two signal transducing $\gamma$ chains. The tetrameric receptor, $\alpha \beta \gamma 2$, is expressed predominantly on tissue-resident mast cells and circulating basophils (4). However, in a proportion of human subjects, mostly atopic patients, a trimeric form of the receptor lacking the $\beta$ chain, $\alpha \gamma 2$, is expressed on other cell types including airway smooth muscle (5), bronchial and intestinal epithelial cells $(6,7)$, Langerhan cells $(8,9)$, dendritic cells $(10,11)$, monocytes (12), and eosinophils (13), neutrophils and platelets (14-16).

Binding of IgE to FceRI on mast cells and basophils enhances FceRI expression (17-21). It is thought that IgE binding to FceRI protects the receptor from being internalized and degraded. On the other hand, IgE binding to FceRI on dendritic cells and monocytes (but not basophils) facilitates the internalization and degradation of IgE-bound FceRI within endolysosomal compartments (22). In addition to showing that IgE levels are important in stabilizing FceRI expression, these observations also indicate a role for FceRI in clearance of serum IgE. Moreover, they suggest that $\alpha \beta \gamma 2$ expressed on mast cells and basophils is predominantly involved in signal transduction leading to mast cell and basophil activation or degranulation, whereas $\alpha \gamma 2$ on antigen presenting cells is mostly involved in IgE-FceRI internalization.

The role of FceRI as the primary activator of mast cells and basophils leading to the release of allergic/inflammatory mediators resulting in IgE-mediated immediate hypersensitivity reactions and allergic inflammation is well-documented (3). Accordingly, FceRI has emerged as a target of biologics for regulating allergic reactions. Currently, anti-IgE monoclonal antibody omalizumab, DARPins, and fusion proteins that coaggregate FceRI and Fc $\gamma$ RIIb are at the forefront of the strategies currently employed or actively being investigated as a means of regulating the expression and/or activation of Fc\&RI for the therapeutic purpose of inhibiting mast cells and basophils (Figure 1).

\section{OMALIZUMAB}

Perhaps the most studied strategy directed against allergic disease is the use of anti-IgE antibodies. Omalizumab (Xolair ${ }^{\circledR}$ ) is a humanized anti-IgE mouse monoclonal antibody that is FDAapproved for the treatment of mild to severe allergic asthma and chronic spontaneous urticaria (23-26). Omalizumab works by binding to circulating free $\operatorname{IgE}$, thereby, reducing the amount that would normally be available to bind FceRI on mast cells and basophils. In an early Phase I study of 15 allergic and asthmatic patients with serum levels of IgE between 187 and $1,210 \mathrm{ng} / \mathrm{ml}$, intravenous injection of omalizumab resulted in reduction of
IgE to $1 \%$ of pre-treatment levels (27). It is widely reported that omalizumab competes with FceRI for the C $3 \varepsilon$ domain of IgE, thus preventing it from binding FceRI-bound $\operatorname{IgE}(28,29)$. However, another study reported that steric hindrance by $\mathrm{C} 2 \varepsilon$ domain, rather than direct competition for site binding, was responsible for the inability of omalizumab to bind FceRI-bound IgE (30). Regardless, omalizumab cannot bind IgE bound to FceRI on mast cells or basophils, and, therefore, does not crosslink IgEbound FceRI to induce the release of allergic mediators. Since binding of IgE to FceRI on mast cells and basophils enhances the expression of FceRI (17-21), the reduction in free IgE by omalizumab leads to diminished expression of FceRI on the surface of mast cells, basophils, and dendritic cells $(21,27,31,32)$. In one study, treatment of atopic individuals with omalizumab for 3 months reduced the expression of FceRI on basophils by $\sim 97 \%$ from $\sim 220,000$ to $\sim 8,300$ receptors per basophil (27). An in vitro study with in situ-matured mast cells from human skin demonstrated that IgE-dependent enhancement of Fc\&RI on human skin mast cells was both prevented and reversed by omalizumab (21). In this study, omalizumab prevented the upregulation of FceRI by $90 \%$ when added simultaneously with polyclonal $\mathrm{IgE}$ at a molar ratio of 2.9 (omalizumab to $\mathrm{IgE}$ ). Omalizumab also dose-dependently decreased FceRI expression on human skin mast cells when added to cultures after Fc\&RI had already been upregulated with IgE, suggesting that omalizumab could disassemble pre-formed IgE:FceRI complexes. This was later confirmed with a cell-free system and human basophils $(30,33)$. The exact mechanism by which omalizumab "strips" IgE off of FceRI is not exactly known, but allosteric destabilization and facilitated dissociation of the IgE:FceRI complex, at least at high concentrations of omalizumab, are suspected (33-36). Human skin mast cells with IgE-enhanced FceRI levels were more sensitive to stimulation with a low dose of anti-FceRI $\mathrm{mAb}$ compared to mast cells with basal levels of FceRI in terms of degranulation, $\mathrm{PGD}_{2}$ biosynthesis, and cytokine production. Reduction of FceRI levels with omalizumab restored sensitivity to stimulation, and mediator release, to basal levels.

The efficacy and safety of omalizumab as treatment against allergic asthma and urticaria has clearly been demonstrated, including as an add-on therapy with traditional treatments such as glucocorticoids $(23,24)$. The therapeutic potential of omalizumab in other IgE-mediated disorders in which Fc\&RI plays a role, including food allergy (37-39), allergic rhinitis (40, $41)$, and atopic dermatitis $(42,43)$ has also been demonstrated. However, one major concern is the duration of the positive effects of omalizumab post-treatment. In one study (44), serum free IgE was reduced by $96-98 \%$, and wheal-and-flare reactions to skin prick tests were significantly reduced in 40 patients with allergic rhinitis who were treated with omalizumb for 28 weeks. However, serum free IgE levels and skin reactivity increased following a reduction in the amount of omalizumab administered, and returned to baseline when therapy was completely discontinued. In another study (45), loss of control of asthma symptoms following discontinuation of omalizumab was recorded in $57 \%$ of the participants with a median timepoint of 13 months after discontinuation. In these studies, FceRI levels on mast cells or basophils was not monitored, but 


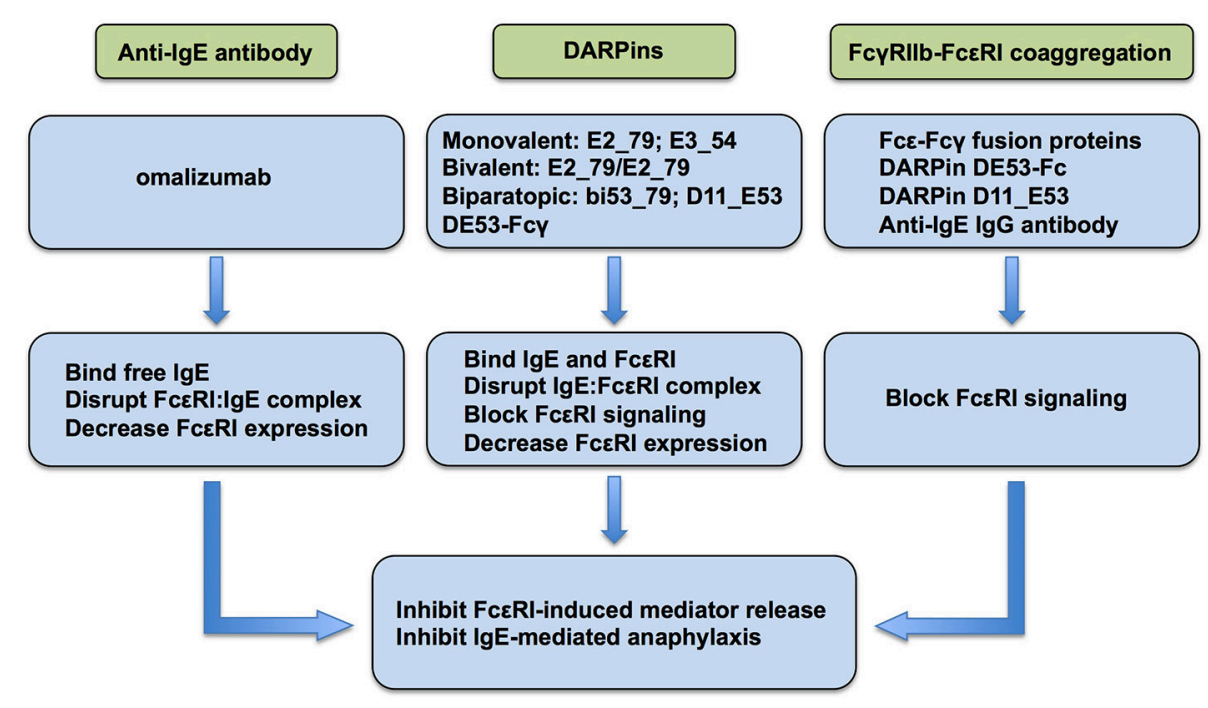

FIGURE 1 | Current strategies to inhibit Fc\&RI signaling in allergic disease.

given that omalizumab decreases FceRI expression on these cell types $(21,27,31,32)$, it is expected that receptor expression increased when treatment was terminated. Thus, treatment with omalizumab could require personalized optimization in terms of dosage and duration of treatment to yield maximal benefits.

Omalizumab as an adjunct to allergen immunotherapy (AIT) against IgE-mediated food allergy and allergic asthma is also currently under investigation (46-50). The main types of AIT are subcutaneous immunotherapy (SCIT) and sublinguinal immunotherapy (SLIT) (51). SCIT and SLIT have been shown to be efficacious for perennial and seasonal allergic respiratory disease $(50,52,53)$. However, SCIT or SLIT are contraindicated for severe or uncontrolled asthma (54). It is thought that pretreatment with omalizumab of patients with severe uncontrolled asthma, which has been shown to be efficacious, could allow AIT in patients that previously could not tolerate it (48, 55). However, studies to investigate AIT in combination with omalizumab are currently lacking. With regard to food allergies, omalizumab treatment in conjunction with oral immunotherapy (OIT) has shown promise in desensitizing allergic patients to peanuts, milk, and multiple food allergens (56-60). Overall, the few reported studies have shown promise for the use of omalizumab in combination with AIT for IgE-mediated disease.

Other anti-IgE antibodies have also been developed and tested including Ligelizumab (QGE031), Quilizumab (MEMP1972A), $\mathrm{XmAb7195}$, and MEDI4212 that might provide additional opportunities for anti-IgE therapy in the future (61). To date, however, none have been shown to be clinically superior to omalizumab, or data is still coming out. In some cases, for example QGE031 for asthma, development has been discontinued. Nevertheless, these or other anti-IgE antibodies could provide additional opportunities for anti-IgE therapy in the future.

\section{DARPINS}

DARPins (designed ankyrin repeat proteins) are a class of small (14-21 kDa) binding proteins comprised of a varying number of stacked ankyrin repeat domains (62), which are one of the most common structural motifs involved in protein-protein interactions in nature. Natural ankyrin repeats are 33 residue motifs comprised of two $\alpha$-helical structures connected by a loop that stack one on top of the other to form ankyrin repeat domains (63). A single DARPin library module is comprised of a 33 residue repeat of which seven residues are randomized and non-conserved. Typically, two to four library modules are genetically fused and flanked by $\mathrm{N}$-cap and C-cap repeats to form one protein domain $(64,65)$. Binding of ankyrin repeat domains can affect stability and effector function of the target protein. The motivation for engineering DARPins was to generate binding proteins that could be used to target proteins with high affinity and specificity, essentially replacing the use of monoclonal antibodies (62).

In one of the first studies (66), two monovalent DARPins (B-A4-85 and C-A3-30) capable of binding two different epitopes of human FceRI $\alpha$ were identified and successfully fused to each other with the flexible linker $\left[\mathrm{Gly}_{4}-\mathrm{Ser}\right]_{4}$. A bispecific DARPin (30/85) was identified as being capable of simultaneously binding $\mathrm{F} c \varepsilon \mathrm{RI} \alpha$ at both epitopes with affinity for FceRI $\alpha$ greater than that of IgE. In in vitro studies, DARPin 30/85 blocked IgE binding to FceRI, and inhibited IgE-induced degranulation of human FceRI $\alpha$-transfected RBL$2 \mathrm{H} 3$ cells to a similar extent as omalizumab. In a similar study (67), two monovalent DARPins, E2_79 and E3_54, that were specific for IgE, and could inhibit IgE-FceRI interactions, were identified. Bivalent proteins were genetically engineered by coupling the monovalent DARPins with the glycine-serine linker. E2_79/E2_79, at 5-fold molar excess with IgE, inhibited the binding of IgE to FceRI $\alpha$ by $>90 \%$, comparable binding 
by omalizumab. E2_79/E2_79 also effectively bound free IgE in serum. The researchers further demonstrated that both the monovalent and bivalent DARPins inhibited IgE-mediated degranulation of FceRI $\alpha$-transfected RBL-2H3 cells. Bivalent DARPin E2_79/E2_79 was particularly effective, exhibiting an $\mathrm{IC}_{50}$ of $0.54 \mathrm{nM}$ compared to $1.77 \mathrm{nM}$ for omalizumab. It was later shown that E2_79, in addition to binding free IgE, could also stimulate the dissociation of pre-formed IgE:Fc\&RI complexes by a facilitated dissociation mechanism at one of two binding sites identified for E2_79 on the IgE:FceRI complex (36). In a separate study, treatment with E2_79 significantly reduced surface expression of FceRI on human ex vivo isolated primary basophils, and inhibited FceRI-induced activation and leukotriene $\mathrm{C} 4\left(\mathrm{LTC}_{4}\right)$ biosynthesis (30). Further, a biparatopic DARPin, bi53_79, which was engineered by fusing the disruptive E2_79 with non-disruptive E3_53 anti-IgE DARPins exhibited a $>10$-fold increase in capacity to disrupt FceRI:IgE complexes, and was more effective at inhibiting anaphylactic reactions in vivo compared with E3_79 alone. Noteworthy, E2_79 and bi53_79 acted faster and were more effective than omalizumab in parallel experiments. These studies demonstrate the therapeutic potential of DARPins as inhibitors of FceRI-induced allergic reactions. Thus, supporting the notion that DARPins have the potential to supplant monoclonal antibodies such as omalizumab as treatment for allergic asthma and other allergic diseases $(62,65)$.

However, DARPins are protein structures, and the potential for immunoreactivity resulting from the production of antiDARPin antibodies should be met with extreme caution. Clearly the immune response to DARPin proteins could be a major limitation in the use of DARPins as therapeutic agents. In addition, the possibility of negative or deleterious effects of inhibiting the activation of FceRI-expressing cell types should also be considered. For example, mast cells and eosinophils play a major role in the clearance and expulsion of parasites particularly helminths. Likewise, mast cell mediators also protect against insect and reptile venom. Thus, blocking the activation of mast cells could inhibit the positive or protective effects associated with FceRI activation. This might be particularly relevant in countries where parasitic infections are endemic. It is argued that DARPins would be more cost effective than monoclonal antibodies because they can be produced in large scale in bacteria; however, the relative cost to human safety must be considered. Importantly, in July 2018, Allergan and Molecular Partners announced that Abicipar pegol, a DARPin engineered to target vascular endothelial growth factor (VEGF), had reached the primary end point in two Phase III trials for the treatment of neovascular agerelated macular degeneration (AMD). In two trials, Abicipar pegol demonstrated non-inferiority to the approved anti-VEGF ranibizumab (Lucentis ${ }^{\circledR}$ ). Of significant concern, however, was a significantly greater incidence of ocular inflammation with Abicipar pegol than Lucentis ${ }^{\circledR}$. Allergan is expected to file Abicipar pegol with the FDA in early 2019. Thus, whether DARPins are safe and efficacious in humans is currently being determined.

\section{CO-AGGREGATION OF FC $\varepsilon$ RI WITH FC $\gamma$ RIIB}

Given the requirement for tyrosine phosphorylation events in the initiation and propagation of FceRI signaling in mast cells and basophils (68-72), one strategy to inhibit FceRI-mediated reactions has been to take advantage of the inhibitory property of Fc $\gamma$ RIIb. Fc $\gamma$ RIIb is the only known inhibitory IgG Fc receptor $(73,74)$. In contrast to FceRI, which utilizes immunoreceptor tyrosine-based activation motif (ITAM), Fc $\gamma$ RIIb utilizes the inhibitory counterpart (ITIM) that, upon receptor activation, recruits $\mathrm{SH} 2$-domain containing phosphatases including SHIP. The phosphatases interfere with the tyrosine-based activation of early signaling molecules resulting in the inhibition of signal transduction (75-77). Fc $\gamma$ RIIb is expressed on human basophils and cord blood-derived mast cells (78-80). It is not constitutively expressed on human skin mast cells (81), but Fc $\gamma$ RIIb expression can be induced in human intestinal mast cells with interferon $\gamma$ (82) and on human basophils with IL-3 (79) suggesting that it could be induced in tissuederived mast cells. Various experiments have been performed demonstrating that co-aggregation of FceRI and Fc $\gamma$ RIIb inhibits IgE-dependent activation and mediator release from mast cells and basophils. In one study (83), it was demonstrated that serotonin release from mouse bone marrow-derived mast cells (BMMCs) sensitized with anti-ova IgE, and then challenged with ova, was dose-dependently inhibited when the BMMCs were challenged with DNP-ova complexed with anti-DNP IgG. The requirement for co-aggregation of $\mathrm{Fc \varepsilon RI}$ and $\mathrm{Fc} \gamma \mathrm{RIIb}$ to inhibit mast cell mediator release was further tested and confirmed in rat basophilic leukemia cells (RBL-2H3) transfected with Fc $\gamma$ RIIb. Another study (84) used a bispecific antibody expressing one Fab fragment specific for human IgE, and the other for Fc $\gamma$ RIIb, to show that simultaneous crosslinking of FceRI and Fc $\gamma$ RIIb inhibited antigen induced histamine release from human cord blood-derived mast cells and peripheral blood basophils. Cassard et al. (79) used an IgG anti-IgE, which binds FceRI-bound IgE via its $\mathrm{Fab}$, and $\mathrm{Fc} \gamma \mathrm{R}$ via their $\mathrm{Fc}$ domain, to demonstrate that co-aggregation of FceRI and Fc $\gamma$ RIIb negatively regulates IgE-induced activation of human and mouse basophils, and release of histamine and IL-4. Furthermore, a comprehensive in vivo study utilizing passive and active immunization of mice determined that FceRI-Fc $\gamma$ RIIb crosslinking contributed significantly to the inhibition of IgE-mediated anaphylaxis by IgG blocking antibodies particularly under low concentrations of IgG blocking antibody (85). Collectively, these studies support the notion that co-aggregation of FceRI and FceRIIb is a viable strategy to limit allergic responses.

Over the years, FcE-Fc $\gamma$ fusion proteins to co-aggregate Fc $\varepsilon$ RI and Fc $\gamma$ RIIb have been investigated. One of the earliest bifunctional fusion proteins that was engineered, termed GE2, is comprised of the hinge-C $\gamma 2-\mathrm{C} \gamma 3$ domains of the human IgG Fc and $\mathrm{C} \varepsilon 2-\mathrm{C} \varepsilon 4$ domains of human $\operatorname{IgE} \mathrm{Fc}$ connected by a 15 amino acid $\left(\mathrm{Gly}_{4} \text {-Ser) }\right)_{3}$ linker (86). Human GE2 was shown to bind to both FceRI and Fc $\gamma$ RII at levels equivalent to human IgE and IgG, respectively. Functionally, GE2 inhibited 
IgE-dependent degranulation of human basophils in timeand dose-dependent manner with maximal inhibition observed when the cells were sensitized with antigen-specific $\operatorname{IgE}$ and GE2 simultaneously. GE2 co-aggregation of FceRI and Fc $\gamma$ RII inhibited Syk phosphorylation, a critical event in FceRI signaling $(87,88)$, and in vivo IgE-induced passive cutaneous anaphylaxis in transgenic mice expressing a human FceRI $\alpha$. Kepley, et al. (78) subsequently used GE2 to further demonstrate that coaggregation of FceRI and Fc $\gamma$ RII on human umbilical cord blood-derived mast cells inhibited degranulation and cytokine production. In a similar study, Mertsching et al. (89) created a murine homolog of human GE2, termed mGE, consisting of $\mathrm{C} \gamma_{2 \mathrm{a}} 2-\mathrm{C} \gamma_{2 \mathrm{a}} 3$ and $\mathrm{C} \varepsilon 2-\mathrm{C} \varepsilon 3-\mathrm{C} \varepsilon 4$ domains connected by the $\left(\mathrm{Gly}_{4} \text {-Ser }\right)_{3}$ linker. mGE was shown to inhibit IgE-dependent degranulation and cytokine production from wild type but not Fc $\gamma$ RIIb-deficient mice BMMCs. mGE also inhibited in vivo passive cutaneous and systemic anaphylaxis in mice, with extended protection. Conversely, mGE treatment increased Fc $\gamma$ RIIb phosphorylation and its association with SHIP and SHP1/2 phosphatases.

In an effort to enhance the efficacy of FceRI-Fc $\gamma$ RIIb co-engagement while eliminating the possibility of FceRI crosslinking, Cemerski et al. (90) engineered a tandem Fc $\varepsilon-F c \gamma$ fusion protein comprised of a murine $\mathrm{Fc} \varepsilon$ domain linked to a human Fcy domain $\mathrm{IgG}_{1}$, which, due to S267E and L328F amino acid substitutions at the Fc $\gamma$ domain, exhibited $>100$ fold greater affinity for human Fc $\gamma$ RIIb compared to the native IgG Fc composition $(91,92)$. This fusion protein was shown to inhibit IgE-dependent degranulation of human Fc $\gamma$ RIIb transgenic BMMCs. However, in the reported experiments, the tandem fusion protein containing the native IgG Fc domain inhibited mast cell degranulation to a similar extent as a control tandem fusion protein lacking affinity for Fc $\gamma$ RIIb. The authors concluded that inhibition of mast cell degranulation by coengagement is more potently suppressed when the tandem fusion protein has higher affinity for Fc $\gamma$ RIIb. To our knowledge, the tandem Fc fusion protein with enhanced affinity for Fc $\gamma$ RIIb has not been compared to the other reported FceRI-Fc $\gamma$ RII fusion proteins, GE2 (86) and hGE2 (89).

Two pre-clinical studies in non-human primates have demonstrated the potential clinical applicability of FceRIFc $\gamma$ RIIb fusion proteins in inhibiting allergic reactions. Zhang et al. (93) first demonstrated that GE2 could inhibit mediator release from mast cells and basophils that had been pre-sensitized with IgE before treatment with GE2 as would be the case in allergic individuals undergoing treatment. The researchers demonstrated that GE2 inhibited Fel d 1 (cat allergen)-induced histamine release from human basophils and lung mast cells from cat allergic patients. Mirroring this, GE2 blocked Fel d 1-induced passive cutaneous anaphylaxis in human FceRI $\alpha$ transgenic mice that were sensitized with serum from cat allergic subjects. GE2 itself was shown to not induce mediator release or induce anaphylaxis. In their pre-clinical study, GE2 was shown to inhibit skin test reactivity to dust mite (Dermatophagoides farinae) allergen in Rhesus monkeys that were naturally allergic to the D. farina allergen. In a later study, Mertsching et al. (89) generated another Fc\&RI-Fc $\gamma$ RIIb fusion protein, termed hGE2, based on the GE2 construct of Zhu et al. (86) absent of any nonnative sequences. hGE2, administered to cynomolgus monkeys that had been sensitized with the roundworm Ascaris suum, was shown to protect the monkeys from cutaneous anaphylaxis induced with $A$. suum extract. The monkeys were reportedly protected from local anaphylaxis for up to three weeks.

Interestingly, a humanized monoclonal anti-IgE antibody (XmAb7195) was reported to have an IgE-binding affinity 5.3fold greater than omalizumab, and 400 times greater binding affinity for Fc $\gamma$ RIIb due to mutations in its Fc region (94). XmAb7195 was shown to block free IgE and inhibit IgE production in B cells by co-engaging IgE and Fc $\gamma$ RIIb. Although XmAb7195 did not bind FceRI-bound IgE (94), this study supports the notion of using anti-IgE IgG antibodies to coaggregate $\mathrm{Fc} \gamma \mathrm{RIIb}$ and $\mathrm{Fc \varepsilon RI}$ to inhibit allergic disease. Firstin-Human Phase 1 clinical trials have been conducted with XmAb7195, but results on safety, tolerability and bioavailability have not been reported (61).

DARPins have also been used to co-aggregate FceRI and Fc $\gamma$ RIIb. Eggel et al. (95) generated an anti-IgE DARPin fusion protein in which DARPin E53, which showed reactivity against a non-FceRI $\alpha$ epitope capable of binding free and receptorbound IgE, was joined via the $\left(\mathrm{Gly}_{4}-\mathrm{Ser}\right)_{3}$ linker to a human $\mathrm{IgG}_{1}$ Fc region. DE53-Fc, as it was named, was shown to not be anaphylactogenic, and inhibited allergen-induced activation of basophils in whole blood samples from allergic donors. In a subsequent study (96), a DE53-Fc mutant construct with increased affinity for Fc $\gamma$ RIIb due to a single site-directed point mutation in the IgG Fc region was shown to be more efficient at co-aggregating $\mathrm{Fc} \varepsilon \mathrm{RI}$ and $\mathrm{Fc} \gamma \mathrm{RIIb}$, resulting in enhanced inhibition of basophil activation. Recently, Zellweger et al. (97) generated DARPin D11_E53, which simultaneously bound human FcyRIIb and FceRI-bound IgE. The bispecific molecule was shown to inhibit allergen-induced degranulation and LTC $_{4}$ biosynthesis in human primary basophils and huFceRI $\alpha-$ expressing mouse BMMCs in vitro, and decreased in vivo passive systemic anaphylaxis induced in huFceRI $\alpha$ transgenic mice. This study demonstrated that Fc $\gamma$ RIIb-mediated inhibition of degranulation requires direct ligation with FceRI, and that DARPins, at least D11_E53, could safely be applied to animals to inhibit anaphylaxis.

\section{CONCLUDING COMMENTS}

The dramatic increase in prevalence of allergies warrants additional research to develop new strategies and therapies to treat allergic disease. At the forefront are the anti-IgE monoclonal antibody omalizumab, DARPins, and fusion proteins that directly or indirectly alter Fc\&RI expression and activation. In order to maximize the use of omalizumab, additional clinical studies are needed to identify allergic diseases against which omalizumab could be effective beyond asthma and spontaneous urticaria. The development of newer anti-IgE antibodies could also have an impact. The development of DARPins hold the promise of targeting FceRI or IgE with greater specificity and better efficacy than monoclonal antibodies without the 
hurdles associated with development of humanized monoclonal antibodies. As potential clinical therapeutics, DARPins also have the potential to reach a broader population since allotypic differences associated with the use of monoclonal antibodies might not factor in their development. However, safety issues regarding immunogenicity due to anti-DARPin antibodies and unwanted effects due to inhibiting positive effects of mast cell activation must be considered. Whether DARPins can supersede monoclonal antibodies remains to be determined. Harnessing the inhibitory properties of Fc $\gamma$ RIIb to inhibit FceRI with fusion proteins also shows promise as evidenced in pre-clinical studies with non-human primates. It is hoped that these strategies will

\section{REFERENCES}

1. Wikstén J, Toppila-Salmi S, Mäkelä M. Primary prevention of airway allergy. Curr Treat Options Allergy (2018) 5:347-55. doi: 10.1007/s40521-018-0190-4

2. Vercelli D. Does epigenetics play a role in human asthma? Allergol Int. (2016) 65:123-6. doi: 10.1016/j.alit.2015.12.001

3. Galli SJ, Tsai M. IgE and mast cells in allergic disease. Nat Med. (2012) 18:693-704. doi: 10.1038/nm.2755

4. Kraft S, Kinet J-P. New developments in FcepsilonRI regulation, function and inhibition. Nat Rev Immunol. (2007) 7:365-78. doi: 10.1038/nri2072

5. Gounni AS, Wellemans V, Yang J, Bellesort F, Kassiri K, Gangloff S, et al. Human airway smooth muscle cells express the high affinity receptor for IgE ( $F c$ epsilon RI): a critical role of $F c$ epsilon RI in human airway smooth muscle cell function. I Immunol. (2005) 175:2613-21. doi: 10.4049/jimmunol.175.4.2613

6. Campbell AM, Vachier I, Chanez P, Vignola AM, Lebel B, Kochan J, et al. Expression of the high-affinity receptor for $\operatorname{IgE}$ on bronchial epithelial cells of asthmatics. Am J Respir Cell Mol Biol. (1998) 19:92-7. doi: $10.1165 /$ ajrcmb.19.1.2648

7. Untersmayr E, Bises G, Starkl P, Bevins CL, Scheiner O, Boltz-Nitulescu G, et al. The high affinity IgE receptor Fc epsilonRI is expressed by human intestinal epithelial cells. PLoS ONE (2010) 5:e9023. doi: 10.1371/journal.pone.0009023

8. Bieber T, la Salle de H, Wollenberg A, Hakimi J, Chizzonite R, Ring J, et al. Human epidermal Langerhans cells express the high affinity receptor for immunoglobulin E (Fc epsilon RI). J Exp Med. (1992) 175:1285-90.

9. Wang B, Rieger A, Kilgus O, Ochiai K, Maurer D, Födinger D, et al. Epidermal Langerhans cells from normal human skin bind monomeric IgE via Fc epsilon RI. J Exp Med. (1992) 175:1353-65.

10. Foster B, Metcalfe DD, Prussin C. Human dendritic cell 1 and dendritic cell 2 subsets express FcepsilonRI: correlation with serum IgE and allergic asthma. J Allergy Clin Immunol. (2003) 112:1132-8. doi: 10.1016/j.jaci.2003. 09.011

11. Maurer D, Fiebiger S, Ebner C, Reininger B, Fischer GF, Wichlas S, et al. Peripheral blood dendritic cells express Fc epsilon RI as a complex composed of Fc epsilon RI alpha- and Fc epsilon RI gamma-chains and can use this receptor for IgE-mediated allergen presentation. J Immunol. (1996) 157:60716.

12. Maurer D, Fiebiger E, Reininger B, Wolff-Winiski B, Jouvin MH, Kilgus O, et al. Expression of functional high affinity immunoglobulin $\mathrm{E}$ receptors $(\mathrm{Fc}$ epsilon RI) on monocytes of atopic individuals. J Exp Med. (1994) 179:745-50.

13. Rajakulasingam K, Till S, Ying S, Humbert M, Barkans J, Sullivan M, et al. Increased expression of high affinity IgE (FcepsilonRI) receptoralpha chain mRNA and protein-bearing eosinophils in human allergeninduced atopic asthma. Am J Respir Crit Care Med. (1998) 158:233-40. doi: 10.1164/ajrccm.158.1.9708106

14. Hasegawa S, Pawankar R, Suzuki K, Nakahata T, Furukawa S, Okumura K, et al. Functional expression of the high affinity receptor for IgE (FcepsilonRI) in human platelets and its' intracellular expression in human megakaryocytes. Blood (1999) 93:2543-51.

15. Gounni AS, Lamkhioued B, Koussih L, Ra C, Renzi PM, Hamid Q. Human neutrophils express the high-affinity receptor for immunoglobulin lead to therapeutics that provide relief to the millions of people worldwide suffering from allergic disease.

\section{AUTHOR CONTRIBUTIONS}

The author confirms being the sole contributor of this work and has approved it for publication.

\section{FUNDING}

GG is supported in part by National Institutes of Health grant P20GM103641.

E (Fc epsilon RI): role in asthma. FASEB J. (2001) 15:940-9. doi: 10.1096/fj.00-0378com

16. Joseph M, Gounni AS, Kusnierz JP, Vorng H, Sarfati M, Kinet JP, et al. Expression and functions of the high-affinity IgE receptor on human platelets and megakaryocyte precursors. Eur J Immunol. (1997) 27:2212-8. doi: 10.1002/eji.1830270914

17. Furuichi K, Rivera J, Isersky C. The receptor for immunoglobulin E on rat basophilic leukemia cells: effect of ligand binding on receptor expression. Proc Natl Acad Sci USA. (1985) 82:1522-5.

18. Lantz CS, Yamaguchi M, Oettgen HC, Katona IM, Miyajima I, Kinet JP, et al. IgE regulates mouse basophil Fc epsilon RI expression in vivo. J Immunol. (1997) 158:2517-21.

19. Yamaguchi M, Lantz CS, Oettgen HC, Katona IM, Fleming T, Miyajima I, et al. IgE enhances mouse mast cell $\mathrm{Fc}$ (epsilon)RI expression in vitro and in vivo: evidence for a novel amplification mechanism in IgE-dependent reactions. $J$ Exp Med. (1997) 185:663-72.

20. Yamaguchi M, Sayama K, Yano K, Lantz CS, Noben-Trauth N, Ra C, et al. IgE enhances $F_{C}$ epsilon receptor I expression and IgE-dependent release of histamine and lipid mediators from human umbilical cord blood-derived mast cells: synergistic effect of IL-4 and IgE on human mast cell Fc epsilon receptor I expression and mediator release. J Immunol. (1999) 162:5455-65.

21. Gomez G, Jogie-Brahim S, Shima M, Schwartz LB. Omalizumab reverses the phenotypic and functional effects of IgE-enhanced $\mathrm{Fc}$ epsilonRI on human skin mast cells. J Immunol. (2007) 179:1353-61. doi: 10.4049/jimmunol.179.2.1353

22. Greer AM, Wu N, Putnam AL, Woodruff PG, Wolters P, Kinet JP, et al. Serum IgE clearance is facilitated by human FceRI internalization. J Clin Invest. (2014) 124:1187-98. doi: 10.1172/JCI68964

23. Israel E, Reddel HK. Severe and difficult-to-treat asthma in adults. $N$ Engl J Med. (2017) 377:965-76. doi: 10.1056/NEJMra1608969

24. Pelaia C, Calabrese C, Terracciano R, de Blasio F, Vatrella A, Pelaia G. Omalizumab, the first available antibody for biological treatment of severe asthma: more than a decade of real-life effectiveness. Ther Adv Respir Dis. (2018) 12:1-16. doi: 10.1177/1753466618810192

25. Saini SS, Kaplan AP. Chronic spontaneous urticaria: the devil's itch. J Allergy Clin Immunol Pract. (2018) 6:1097-106. doi: 10.1016/j.jaip.2018.04.013

26. Maurer M, Rosén K, Hsieh HJ, Saini S, Grattan C, Gimenéz-Arnau A, et al. Omalizumab for the treatment of chronic idiopathic or spontaneous urticaria. N Engl J Med. (2013) 368:924-35. doi: 10.1056/NEJMoa1215372

27. MacGlashan DW, Bochner BS, Adelman DC, Jardieu PM, Togias A, McKenzie-White J, et al. Down-regulation of Fc(epsilon)RI expression on human basophils during in vivo treatment of atopic patients with anti-IgE antibody. J Immunol. (1997) 158:1438-45.

28. Qiao CX, Lv M, Guo LM, Yu M, Li Y, Lin Z, et al. Inhibition of IgE activity to bind its high affinity receptor $\left(\mathrm{F}_{\mathrm{c} \varepsilon \mathrm{RI}} \alpha\right)$ by mouse anti-IgE C $\varepsilon 3 \sim 4$ monoclonal antibody (QME5). Int J Biomed Sci. (2009) 5:336-44.

29. Zheng L, Li B, Qian W, Zhao L, Cao Z, Shi S, et al. Fine epitope mapping of humanized anti-IgE monoclonal antibody omalizumab. Biochem Biophys Res Commun. (2008) 375:619-22. doi: 10.1016/j.bbrc.2008.08.055

30. Eggel A, Baravalle G, Hobi G, Kim B, Buschor P, Forrer P, et al. Accelerated dissociation of $\operatorname{IgE}-\mathrm{F} c \varepsilon \mathrm{RI}$ complexes by disruptive inhibitors 
actively desensitizes allergic effector cells. J Allergy Clin Immunol. (2014) 133:1709-19.e8. doi: 10.1016/j.jaci.2014.02.005

31. Beck LA, Marcotte GV, Macglashan D, Togias A, Saini S. Omalizumabinduced reductions in mast cell Fce psilon RI expression and function. $J$ Allergy Clin Immunol. (2004) 114:527-30. doi: 10.1016/j.jaci.2004.06.032

32. Prussin C, Griffith DT, Boesel KM, Lin H, Foster B, Casale TB. Omalizumab treatment downregulates dendritic cell FcepsilonRI expression. J Allergy Clin Immunol. (2003) 112:1147-54. doi: 10.1016/j.jaci.2003.10.003

33. Maggi L, Rossettini B, Montaini G, Matucci A, Vultaggio A, Mazzoni A, et al. Omalizumab dampens type 2 inflammation in a group of long-term treated asthma patients and detaches IgE from FceRI. Eur J Immunol. (2018) 16:2005-14. doi: 10.1002/eji.201847668

34. Davies AM, Allan EG, Keeble AH, Delgado J, Cossins BP, Mitropoulou AN, et al. Allosteric mechanism of action of the therapeutic anti-IgE antibody omalizumab. J Biol Chem. (2017) 292:9975-87. doi: 10.1074/jbc.M117.776476

35. Serrano-Candelas E, Martinez-Aranguren R, Valero A, Bartra J, Gastaminza G, Goikoetxea MJ, et al. Comparable actions of omalizumab on mast cells and basophils. Clin Exp Allergy (2016) 46:92-102. doi: 10.1111/cea.12668

36. Kim B, Eggel A, Tarchevskaya SS, Vogel M, Prinz H, Jardetzky TS. Accelerated disassembly of IgE-receptor complexes by a disruptive macromolecular inhibitor. Nature (2012) 491:613-7. doi: 10.1038/nature11546

37. Abdel-Gadir A, Schneider L, Casini A, Charbonnier L-M, Little SV, Harrington T, et al. Oral immunotherapy with omalizumab reverses the Th2 cell-like programme of regulatory $\mathrm{T}$ cells and restores their function. Clin Exp Allergy (2018) 48:825-36. doi: 10.1111/cea.13161

38. Dantzer JA, Wood RA. The use of omalizumab in allergen immunotherapy. Clin Exp Allergy (2018) 48:232-40. doi: 10.1111/cea.13084

39. Andorf S, Purington N, Block WM, Long AJ, Tupa D, Brittain E, et al. Anti$\mathrm{IgE}$ treatment with oral immunotherapy in multifood allergic participants: a double-blind, randomised, controlled trial. Lancet Gastroenterol Hepatol. (2018) 3:85-94. doi: 10.1016/S2468-1253(17)30392-8

40. Tsabouri S, Tseretopoulou X, Priftis K, Ntzani EE. Omalizumab for the treatment of inadequately controlled allergic rhinitis: a systematic review and meta-analysis of randomized clinical trials. J Allergy Clin Immunol Pract. (2014) 2:332-40.e1. doi: 10.1016/j.jaip.2014.02.001

41. Masieri S, Cavaliere C, Begvarfaj E, Rosati D, Minni A. Effects of omalizumab therapy on allergic rhinitis: a pilot study. Eur Rev Med Pharmacol Sci. (2016) 20:5249-55.

42. Holm JG, Agner T, Sand C, Thomsen SF. Omalizumab for atopic dermatitis: case series and a systematic review of the literature. Int J Dermatol. (2017) 56:18-26. doi: 10.1111/ijd.13353

43. Kim DH, Park KY, Kim BJ, Kim MN, Mun SK. Anti-immunoglobulin E in the treatment of refractory atopic dermatitis. Clin Exp Dermatol. (2013) 38:496-500. doi: 10.1111/j.1365-2230.2012.04438.x

44. Corren J, Shapiro G, Reimann J, Deniz Y, Wong D, Adelman D, et al. Allergen skin tests and free IgE levels during reduction and cessation of omalizumab therapy. J Allergy Clin Immunol. (2008) 121:506-11. doi: 10.1016/j.jaci.2007.11.026

45. Molimard M, Mala L, Bourdeix I, Le Gros V. Observational study in severe asthmatic patients after discontinuation of omalizumab for good asthma control. Respir Med. (2014) 108:571-6. doi: 10.1016/j.rmed.2014.02.003

46. Kopp MV, Hamelmann E, Bendiks M, Zielen S, Kamin W, Bergmann $\mathrm{K}-\mathrm{C}$, et al. Transient impact of omalizumab in pollen allergic patients undergoing specific immunotherapy. Pediatr Allergy Immunol. (2013) 24:42733. doi: 10.1111 pai. 12098

47. Kuehr J, Brauburger J, Zielen S, Schauer U, Kamin W, Berg Von A, et al. Efficacy of combination treatment with anti-IgE plus specific immunotherapy in polysensitized children and adolescents with seasonal allergic rhinitis. $J$ Allergy Clin Immunol. (2002) 109:274-80. doi: 10.1067/mai.2002.121949

48. Braido F, Corsico A, Rogkakou A, Ronzoni V, Baiardini I, Canonica GW. The relationship between allergen immunotherapy and omalizumab for treating asthma. Exp Rev Respir Med. (2015) 9:129-34. doi: $10.1586 / 17476348.2015 .1000866$

49. Chen M, Land M. The current state of food allergy therapeutics. Hum Vaccin Immunother. (2017) 13:2434-42. doi: 10.1080/21645515.2017.1359363

50. Tsabouri S, Mavroudi A, Feketea G, Guibas GV. Subcutaneous and sublingual immunotherapy in allergic asthma in children. Front Pediatric. (2017) 5:82. doi: $10.3389 /$ fped.2017.00082
51. Passalacqua G, Canonica GW, Bagnasco D. Benefit of SLIT and SCIT for allergic rhinitis and asthma. Curr Allergy Asthma Rep. (2016) 16:88. doi: 10.1007/s11882-016-0666-x

52. Burks AW, Calderon MA, Casale T, Cox L, Demoly P, Jutel M, et al. Update on allergy immunotherapy: american academy of allergy, asthma \& immunology/European academy of allergy and clinical immunology/PRACTALL consensus report. J Allergy Clin Immunol. (2013) 1288-96.e3. doi: 10.1016/j.jaci.2013.01.049

53. Akdis CA. Therapies for allergic inflammation: refining strategies to induce tolerance. Nat Med. (2012) 18:736-49. doi: 10.1038/nm.2754

54. Pitsios C, Demoly P, Bilò MB, Gerth van Wijk R, Pfaar O, Sturm GJ, et al. Clinical contraindications to allergen immunotherapy: an EAACI position paper. Allergy (2015) 70:897-909. doi: 10.1111/all.12638

55. Yukselen A. Allergen-specific immunotherapy in pediatric allergic asthma. Asia Pac Allergy (2016) 6:139-48. doi: 10.5415/apallergy.2016.6.3.139

56. Schneider LC, Rachid R, LeBovidge J, Blood E, Mittal M, Umetsu DT. A pilot study of omalizumab to facilitate rapid oral desensitization in highrisk peanut-allergic patients. J Allergy Clin Immunol. (2013) 132:1368-74. doi: 10.1016/j.jaci.2013.09.046

57. Nadeau KC, Schneider LC, Hoyte L, Borras I, Umetsu DT. Rapid oral desensitization in combination with omalizumab therapy in patients with cow's milk allergy. J Allergy Clin Immunol. (2011) 127:1622-4. doi: 10.1016/j.jaci.2011.04.009

58. Bégin P, Dominguez T, Wilson SP, Bacal L, Mehrotra A, Kausch B, et al. Phase 1 results of safety and tolerability in a rush oral immunotherapy protocol to multiple foods using Omalizumab. Allergy Asthma Clin Immunol. (2014) 10:7. doi: $10.1186 / 1710-1492-10-7$

59. Martorell-Calatayud C, Michavila-Gómez A, Martorell-Aragonés A, Molini-Menchón N, Cerdá-Mir JC, Félix-Toledo R, et al. Anti-IgEassisted desensitization to egg and cow's milk in patients refractory to conventional oral immunotherapy. Pediatr Allergy Immunol. (2016) 27:544-6. doi: 10.1111/pai.12567

60. MacGinnitie AJ, Rachid R, Gragg H, Little SV, Lakin P, Cianferoni A, et al. Omalizumab facilitates rapid oral desensitization for peanut allergy. J Allergy Clin Immunol. (2017) 139:873-81.e8. doi: 10.1016/j.jaci.2016.08.010

61. Balbino B, Conde E, Marichal T, Starkl P, Reber LL. Approaches to target IgE antibodies in allergic diseases. Pharmacol Ther. (2018) 191:50-64. doi: 10.1016/j.pharmthera.2018.05.015

62. Stumpp MT, Binz HK, Amstutz P. DARPins: a new generation of protein therapeutics. Drug Discov Today (2008) 13:695-701. doi: 10.1016/j.drudis.2008.04.013

63. Li J, Mahajan A, Tsai M-D. Ankyrin repeat: a unique motif mediating protein-protein interactions. Biochemistry (2006) 45:15168-78. doi: 10.1021/bi062188q

64. Binz HK, Stumpp MT, Forrer P, Amstutz P, Plückthun A. Designing repeat proteins: well-expressed, soluble and stable proteins from combinatorial libraries of consensus ankyrin repeat proteins. J Mol Biol. (2003) 332:489-503. doi: 10.1016/S0022-2836(03)00896-9

65. Plückthun A. Designed ankyrin repeat proteins (DARPins): binding proteins for research, diagnostics, and therapy. Annu Rev Pharmacol Toxicol. (2015) 55:489-511. doi: 10.1146/annurev-pharmtox-010611-134654

66. Eggel A, Baumann MJ, Amstutz P, Stadler BM, Vogel M. DARPins as bispecific receptor antagonists analyzed for immunoglobulin E receptor blockage. J Mol Biol. (2009) 393:598-607. doi: 10.1016/j.jmb.2009.08.014

67. Baumann MJ, Eggel A, Amstutz P, Stadler BM, Vogel M. DARPins against a functional IgE epitope. Immunol Lett. (2010) 133:78-84. doi: 10.1016/j.imlet.2010.07.005

68. Kambayashi T, Koretzky GA. Proximal signaling events in Fc epsilon RImediated mast cell activation. J Allergy Clin Immunol. (2007) 119:544-52. doi: 10.1016/j.jaci.2007.01.017

69. Odom S, Gomez G, Kovarova M, Furumoto Y, Ryan JJ, Wright HV, et al. Negative regulation of immunoglobulin E-dependent allergic responses by Lyn kinase. J Exp Med. (2004) 199:1491-502. doi: 10.1084/jem.200 40382

70. Parravicini V, Gadina M, Kovarova M, Odom S, Gonzalez-Espinosa C, Furumoto $\mathrm{Y}$, et al. Fyn kinase initiates complementary signals required for IgE-dependent mast cell degranulation. Nat Immunol. (2002) 3:741-8. doi: $10.1038 /$ ni817 
71. Gomez G, Gonzalez-Espinosa C, Odom S, Baez G, Cid ME, Ryan JJ, et al. Impaired FceRI-dependent gene expression and defective eicosanoid and cytokine production as a consequence of Fyn deficiency in mast cells. $J$ Immunol. (2005) 175:7602-10. doi: 10.4049/jimmunol.175.11.7602

72. Rivera J, Cordero JR, Furumoto Y, Luciano-Montalvo C, Gonzalez-Espinosa C, Kovarova M, et al. Macromolecular protein signaling complexes and mast cell responses: a view of the organization of IgE-dependent mast cell signaling. Mol Immunol. (2002) 38:1253-8. doi: 10.1016/S0161-5890(02)00072-X

73. Rosales C. Fc $\gamma$ receptor heterogeneity in leukocyte functional responses. Front Immunol. (2017) 8:280. doi: 10.3389/fimmu.2017.00280

74. Nimmerjahn F, Ravetch JV. Fcgamma receptors as regulators of immune responses. Nat Rev Immunol. (2008) 8:34-47. doi: 10.1038/nri2206

75. Ono M, Bolland S, Tempst P, Ravetch JV. Role of the inositol phosphatase SHIP in negative regulation of the immune system by the receptor Fc(gamma)RIIB. Nature (1996) 383:263-6. doi: 10.1038/383263a0

76. Ono M, Okada H, Bolland S, Yanagi S, Kurosaki T, Ravetch JV. Deletion of SHIP or SHP-1 reveals two distinct pathways for inhibitory signaling. Cell (1997) 90:293-301.

77. Bolland S, Ravetch JV. Inhibitory pathways triggered by ITIM-containing receptors. In: Dixon FJ, editor. Advances in Immunology. New York, NY: Elsevier (1999). p. 149-77.

78. Kepley CL, Taghavi S, Mackay G, Zhu D, Morel PA, Zhang K, et al. Coaggregation of FcgammaRII with FcepsilonRI on human mast cells inhibits antigen-induced secretion and involves SHIP-Grb2-Dok complexes. J Biol Chem. (2004) 279:35139-49. doi: 10.1074/jbc.M404318200

79. Cassard L, Jönsson F, Arnaud S, Daëron M. Fc $\gamma$ receptors inhibit mouse and human basophil activation. J Immunol. (2012) 189:2995-3006. doi: 10.4049/jimmunol.1200968

80. Cady CT, Powell MS, Harbeck RJ, Giclas PC, Murphy JR, Katial RK, et al. IgG antibodies produced during subcutaneous allergen immunotherapy mediate inhibition of basophil activation via a mechanism involving both FcgammaRIIA and FcgammaRIIB. Immunol Lett. (2010) 130:57-65. doi: 10.1016/j.imlet.2009.12.001

81. Zhao W, Kepley CL, Morel PA, Okumoto LM, Fukuoka Y, Schwartz LB. Fc gamma RIIa, not Fc $\gamma$ RIIb, is constitutively and functionally expressed on skin-derived human mast cells. J Immunol. (2006) 177:694-701. doi: 10.4049/jimmunol.177.1.694

82. Sellge G, Barkowsky M, Kramer S, Gebhardt T, Sander LE, Lorentz A, et al. Interferon $\gamma$ regulates growth and controls $\mathrm{Fc} \gamma$ receptor expression and activation in human intestinal mast cells. BMC Immunol. (2014) 15:27. doi: 10.1186/1471-2172-15-27

83. Daëron M, Malbec O, Latour S, Arock M, Fridman WH. Regulation of highaffinity IgE receptor-mediated mast cell activation by murine low-affinity IgG receptors. J Clin Invest. (1995) 95:577-85. doi: 10.1172/JCI117701

84. Tam SW, Demissie S, Thomas D, Daëron M. A bispecific antibody against human IgE and human FcgammaRII that inhibits antigen-induced histamine release by human mast cells and basophils. Allergy (2004) 59:772-80. doi: 10.1111/j.1398-9995.2004.00332.x

85. Strait RT, Morris SC, Finkelman FD. IgG-blocking antibodies inhibit IgE-mediated anaphylaxis in vivo through both antigen interception and Fc gamma RIIb cross-linking. J Clin Invest. (2006) 116:833-41. doi: $10.1172 /$ JCI 25575

86. Zhu D, Kepley CL, Zhang M, Zhang K, Saxon A. A novel human immunoglobulin $\mathrm{Fc}$ gamma $\mathrm{Fc}$ epsilon bifunctional fusion protein inhibits Fc epsilon RI-mediated degranulation. Nat Med. (2002) 8:518-21. doi: $10.1038 / \mathrm{nm} 0502-518$

87. Siraganian RP, Zhang J, Suzuki K, Sada K. Protein tyrosine kinase Syk in mast cell signaling. Mol Immunol. (2002) 38:1229-33. doi: 10.1016/S0161-5890(02)00068-8

88. Costello PS, Turner M, Walters AE, Cunningham CN, Bauer PH, Downward J, Tybulewicz VL. Critical role for the tyrosine kinase Syk in signalling through the high affinity IgE receptor of mast cells. Oncogene (1996) 13:2595-605.

89. Mertsching E, Bafetti L, Hess H, Perper S, Giza K, Allen LC, et al. A mouse Fcgamma-Fcepsilon protein that inhibits mast cells through activation of FcgammaRIIB, SH2 domain-containing inositol phosphatase 1, and SH2 domain-containing protein tyrosine phosphatases. J Allergy Clin Immunol. (2008) 121:441-7.e5. doi: 10.1016/j.jaci.2007.08.051

90. Cemerski S, Chu SY, Moore GL, Muchhal US, Desjarlais JR, Szymkowski DE. Suppression of mast cell degranulation through a dual-targeting tandem IgE-IgG Fc domain biologic engineered to bind with high affinity to Fc $\gamma$ RIIb. Immunol Lett. (2012) 143:34-43. doi: 10.1016/j.imlet.2012. 01.008

91. Chu SY, Vostiar I, Karki S, Moore GL, Lazar GA, Pong E, et al. Inhibition of B cell receptor-mediated activation of primary human B cells by coengagement of CD19 and FcgammaRIIb with Fc-engineered antibodies. Mol Immunol. (2008) 45:3926-33. doi: 10.1016/j.molimm.2008.06.027

92. Moore GL, Chen H, Karki S, Lazar GA. Engineered Fc variant antibodies with enhanced ability to recruit complement and mediate effector functions. MAbs (2010) 2:181-9. doi: 10.4161/mabs.2.2.11158

93. Zhang K, Kepley CL, Terada T, Zhu D, Perez H, Saxon A. Inhibition of allergen-specific IgE reactivity by a human Ig Fcgamma-Fcepsilon bifunctional fusion protein. J Allergy Clin Immunol. (2004) 114:321-7. doi: $10.1016 /$ j.jaci.2004.03.058

94. Chu SY, Horton HM, Pong E, Leung IWL, Chen H, Nguyen D-H, et al. Reduction of total IgE by targeted coengagement of IgE B-cell receptor and Fc $\gamma$ RIIb with Fc-engineered antibody. J Allergy Clin Immunol. (2012) 129:1102-15. doi: 10.1016/j.jaci.2011.11.029

95. Eggel A, Buschor P, Baumann MJ, Amstutz P, Stadler BM, Vogel M. Inhibition of ongoing allergic reactions using a novel anti-IgE DARPin-Fc fusion protein. Allergy (2011) 66:961-8. doi: 10.1111/j.1398-9995.2011.02546.x

96. Buschor P, Eggel A, Zellweger F, Stadler BM, Vogel M. Improved Fc $\gamma$ RIIb targeting functionally translates into enhanced inhibition of basophil activation. Int Arch Allergy Immunol (2014) 163:206-14. doi: 10.1159/000358487

97. Zellweger F, Gasser P, Brigger D, Buschor P, Vogel M, Eggel A. A novel bispecific DARPin targeting Fc $\gamma$ RIIB and FceRI-bound IgE inhibits allergic responses. Allergy (2017) 72:1174-83. doi: 10.1111/all.13109

Conflict of Interest Statement: The author declares that the research was conducted in the absence of any commercial or financial relationships that could be construed as a potential conflict of interest.

Copyright (C) 2019 Gomez. This is an open-access article distributed under the terms of the Creative Commons Attribution License (CC BY). The use, distribution or reproduction in other forums is permitted, provided the original author(s) and the copyright owner(s) are credited and that the original publication in this journal is cited, in accordance with accepted academic practice. No use, distribution or reproduction is permitted which does not comply with these terms. 